Ключевые слова: Новая украинская школа, основные компетентности в естественных науках и технологиях, научный метод познания, теоретические и экспериментальные методы физики, учебныій физический эксперимент.

PODOPRYGoRa N. V. Conceptual basis of development of information and digital competence of future specialists of computer technologies.

National priorities related to improving the quality of professional training of future science teachers and the transition of Ukrainian higher education to new indicators of quality of education (competence) have actualized the need for specialists capable of providing favorable conditions for the comprehensive development of subjects of the educational process. In this context, special attention should be paid to reforming the process of training future specialists whose professional activity is aimed at forming holistic ideas about the system of natural sciences, which, at the same time, requires not only basic natural and mathematical knowledge but also those that provide the ability of the future teacher their realization in professional activity, readiness to innovate in both the content and technology of science education.

The article is devoted to the problem of training future teachers of natural sciences to the formation of core competencies in the natural sciences and technologies, scientific understanding of the knowledge of nature and modern technologies, as well as the willingness to apply it in practice. There are presented the authors' methodical developments of organization and realization of the experimental cycle of scientific cognition in the process of arrangement of experimental Physics problems. It is proposed to consider an experimental task in physics to determine the quality factor of a mathematical pendulum. The laboratory equipment includes simple digital measuring devices and author's home-made equipment that makes possible realization of the offered problems in an educational physics experiment.

Keywords: The New Ukrainian School, the basic competences in natural sciences and technologies, scientific method of knowledge, theoretical and experimental methods of physics, educational physical experiment.

DOI: https://doi.org/10.31392/NZ-npu-143.2019.22

УДК 37.091.4Тамм

Садовий М. І., Проценко Є. А., Донець Н. В.

\title{
ОКРЕМІ АСПЕКТИ ВИКОРИСТАННЯ НАУКОВО-ПЕДАГОГІЧНОЇ СПАДЩИНИ І. Є. ТАММА У СУЧАСНОМУ ОСВІТНЬОМУ ПРОСТОРІ УКРАЇНИ
}

Нині в державі склалася не краща ситуаџія з поповненням науковими кадрами новітньої генерації, тому є проблематичним стимулювати створення умов задля зацікавлення та залучення перспективної молоді до наукової діяльності. Методика залучення молоді до наукової діяльності, що використовувалася І. С. Таммом, не втратила ефективності і у наш час, $\epsilon$ прогресивною, інноваційною, дієвою та такою, щу добре себе зарекомендувала роками.

У статті показано важливість, актуальність науково-педагогічних ідей I. С. Тамма для сучасного етапу розвитку педагогіки та історії педагогіки. Розкрито систему залучення молоді до наукової діяльності на основі дослідження науково-педагогічної спадщини I. Є. Тамма в закладах вищої освіти України. Серед таких закладів вищої освіти можна виокремити 
наукові школи Центральноукраїнського педагогічного університету ім. В. Винниченка. Робота, щзо проводиться в изьому напрямі, є результативною та такою, щзо потребує висвітлення. У статті показані результати семирічної діяльності Лабораторії дидактики фізики, технологій i професійної освіти (ЛАБДФТПО) Інституту педагогіки НАПН Украӥни у Центральноукраӥнському державному педагогічному університеті імені Володимира Винниченка, розкритті підходи до організаиії діяльності молодих науковців. Використання інноваційної методики залучення молоді до наукової діяльності (яка в ичілому відображає стиль та методику роботи I. С. Тамма) дає свої позитивні результати, що детальніме розглянуто в cmammi.

Ключові слова: І. С. Тамм, освіта, педагогічна спадщина.

За роки незалежності в Україні здійснюється перебудова структури і змісту наукових установ, закладів вищої освіти в частині підготовки кадрів здатних до науково-дослідної роботи. Від якості кадрового наукового складу залежить ефективність відтворення інтелектуального потенціалу українського суспільства, окреслення його місця у світовому науковому просторі. Нині в державі склалася не краща ситуація з поповненням науковими кадрами новітньої генерації, тому $є$ проблемою стимулювати створення умов задля зацікавлення та залучення перспективної молоді до наукової діяльності. Методика залучення молоді до наукової діяльності, що використовувалася І.Є. Таммом не втратила ефективності і у наш час, $є$ прогресивною, інноваційною, дієвою та такою, що добре себе зарекомендувала роками.

Більшість наукових шкіл закладів вищої освіти України ефективно використовують у своїй діяльності методичну систему роботи І. Є. Тамма. Серед таких ЗВО можна виокремити наукові школи ЦДПУ ім. В. Винниченка. Робота, що проводиться в даному напрямі $€$ результативною та такою, що потребує висвітлення.

Ігор Євгенович Тамм - це вчений-теоретик, педагог, який не міг без наукової роботи, без співпраці з молоддю. Результатом прагнення до активізації наукової роботи стало створення на фрізичному факультеті МДУ семінару з проблем теоретичної фрізики, який був і нині є постійно діючим. 31934 р. даний семінар працював у Фізичному інституту АН СРСР та швидко завоював серед молоді наукову популярність. На семінарі, створеного І. Є. Таммом, всі були рівні, які б ідеї не обговорювалися, навіть абсурдні. Принцип роботи вченого з молодими науковцями полягав у тому, що ідея кожного вважалася цікавою, важливою та такою, що потребує розгляду та детального вивчення. Таке середовище сприяло виявленню та розвитку науковців, особливо з теоретичної фрізики.

І. Є. Тамм був активним керівником і часто виступав зі своїми доповідями. Провівши аналіз тем доповідей вченого ми приходимо до висновку, що характерними особливостями основ та методики функціонування школи І. $€$. Тамма є широта охоплення актуальних проблем досліджень, якість, математична точність. Виокремлюється глибока математична культура вченого. Причому створення школи було не самоціллю Ігоря Євгеновича. Його життя є єдиним неперервним поривом наукової думки у світ нерозгаданих таємниць науки, де поєднувався дослідницький талант, психолого-педагогічний хист і особистісні якості "непосиди". Висока ерудованість, природна обдарованість, результати наукових досліджень визнані світовим науковим співтовариством, любов до теоретичної фізики, глобального масштабу моральний авторитет, уміння організувати толерантну і глибоку дискусію, поєднання доброзичливості і 
вимогливості слугували його успішності серед науковців та громадськості .

І. Є. Тамм завжди проводив активну діяльність з підтримки не лише наукової, ай матеріальної талановитої молоді. Вона проявлялася у наступному:

- звертався до декана фрізичного фракультету МДУ з проханням визначити здібного студента з малозабезпеченої сім"ї і виділяв із власних коштів щомісячну стипендію до завершення навчання. Така "іменна стипендія" без оголошення джерела фрінансування проіснувала із 1956 р. [1];

- виділяв власні кошти для придбання речей молодим науковцям (студенту Б. М. Завадовському на взуття, який пізніше став видатним вченим у галузі фрізіології та еволюції тварин, доктор сільськогосподарських наук (1934), профресор, академік ВАСХНІЛ) [1];

- добивався від Уряду встановлення іменних стипендій (запроваджена у державі Ленінська стипендія) найбільш талановитим студентами [1];

- формування у ВЗО окремих студентських груп для спеціальної підготовки науковців в галузях новітніх технологій (теоретична фрізики, Всесвіт, єдина теорія поля та ін.);

- у 1934 р. створив у Фізичному інституті Академії наук СРСР науковий семінар, який працював щомісячно, до роботи якого залучав талановиту молоді 3 усієї держави [2];

-у ведучих наукових центрах з теоретичної фрізики Новосибірська, Свердловська, Томська, Харкова, Києва, Дніпропетровська був штатним науковим консультантом [2];

- ініціював у МДУ, МІФІ та інших наукових центрах запровадження проведення учнівських олімпіад, та у столицях союзних республік започаткування фізико-математичних шкіл-інтернатів, зокрема при Київському університеті ім. Т. Г. Шевченка.

Важливим, необхідним, таким що сприятиме розвитку сучасної освіти України є використання науково-педагогічної спадщини І. Є. Тамма. Ефективною $€$ робота наукових шкіл закладів вищої освіти України в даному напрямку. Зокрема, 29 березня 2013 року на фрізико-математичному фракультеті Кіровоградського державного педагогічного університету імені Володимира Винниченка проведена Х Всеукраїнська наукова конференція студентів та молодих науковців “Фізика. Нові технології навчання" присвячена річниці отримання І.Є. Таммом Нобелівської премії з фрізики (організатор: к. пед. н, доцент кафедри фрізики та методики її викладання І. В. Сальник). За результатами конференції було видано збірник “Фізика. Нові технології навчання" [4]. В цьому збірнику в секції “Фізика. Історія фрізики та техніки” надруковані статті студентів та викладачів фрізикоматематичного факультету, в яких розкритті різні сторони діяльності І. Є. Тамма, зокрема: М. Бурмістров, Р. Я. Ріжняк “І. Є. Тамм поза фрізикою”, А. Добровольська, О. М. Трифонова "Внесок родини Тамма у розвиток Кіровоградської землі", І. Жиган, М. І. Садовий “І. Є. Тамм і Єлисаветград”, О. Журавський, М. І. Садовий "Атом літію, український фрізико-технічний інститут ім. К. Д. Синельникова", В. Заболотна, О. М. Трифонова "Роль І. Є. Тамма у створенні водневої бомби", О. Заплава, О. М. Трифонова "Роль І. Є. Тамма в обґрунтуванні випромінювання Вавілова-Черенкова", О. Книш, М. І. Садовий "Наукова школа І. Є. Тамма" [4].

Іншим прикладом роботи наукових шкіл закладів вищої освіти є семирічний 
досвід діяльності Лабораторії дидактики фрізики, технологій і профресійної освіти (ЛабДФТПО) Інституту педагогіки НАПН України у Центральноукраїнському державному педагогічному університеті імені Володимира Винниченка, керівники М. І. Садовий, О. М. Трифонова, яка утворена спільною угодою від 23 березня 2012 р. між Центральноукраїнським державним педагогічним університетом імені Володимира Винниченка (ЦДПУ) та Інститутом педагогіки Національної академії педагогічних наук України (НАПНУ) [3].

Одним із ії напрямків $€$ послідовне дослідження науково-педагогічної спадщини, творчої, особистісної, громадської діяльності Ігоря Євгеновича Тамма, його наукової школи, творчого начало семінару у відділі теоретичної фрізики Фізичного інституту АН СРСР (виконавці: М.І. Садовий, Р.Я.Ріжняк, О. М. Трифонова, О.В. Єкименкова, Є. А. Проценко, Н.В.Донець) за останні 7 років досліджень надруковано 16 статей у фрахових та наукометричних виданнях, видано три посібники, проведено декілька науково-практичних конференцій.

ЛабДФТПО у своїй діяльності реалізує такі заходи [3]:

- забезпечує проведення теоретико-методичних досліджень з актуальних проблем дидактики фрізики та технологій в закладах вищої та середньої освіти ;

- організовує реалізацію висновків наукових досліджень та практичних розробок у практику роботи закладів освіти, апробацію нових актуальних технологій навчання у закладах загальної середньої освіти та вищої освіти, здійснює підготовку інноваційних навчальних та навчально-методичних посібників, методичних рекомендацій та підручників;

- забезпечує керівництво та наукове консультування у науковій роботі студентів, аспірантів, здійснює координацію діяльності докторантів та пошукувачів;

- планує та обґрунтовує заходи з: підвищення якості підготовки наукових фахівців; ефективності і результативності професійної діяльності науковців; організації проведення міжнародних науково-практичних конференцій та семінарів;

- розробляє компоненти формування компетентнісних і світоглядних якостей майбутнього фахівця медичного профілю, окреслення системи показників оцінки якості навчання медичної і біологічної фрізики. Зокрема, підготовлено збірник застосування в освітній практиці системи рівневих фрізичних задач і завдань професійно зорієнтованого змісту, що сприяє реалізації механізмів інтеграції репродуктивної і творчої навчально-пізнавальної діяльності студентів;

- виробляє рекомендації з реалізації здоров'язбережувального компоненту освітнього процесу в умовах використання інноваційних технологій. Зокрема, формуванню інформаційно-цифрової компетентності засобами STEM освіти, робототехніки, застосування вимірювального комплекту “PHYWE", для створення нестресогенного психологічного мікроклімату та саморегуляції суб'єкту навчання (імпульсивність, агресивність, тривожність перебувають у особистості в межах норми).

Також членами ЛабДФТПО проведено міжнародну науково-практичну конференцію присвячені 120-річчю від дня народження Ігоря Євгеновича Тамма [3]. Основні напрямки роботи конференції охоплювали: інноваційні підходи до формування педагогічних складових навчального фізичного експерименту; внесок 
наукової школи І. Є. Тамма у становлення методичної думки з фрізики; розвиток принципу історизму в освітньому процесі; розвиток змісту фрізичної освіти в умовах сучасної парадигми.

Загалом у конференції прийняли участь 74 науковці професори, викладачі, молоді вчені, аспіранти та студенти провідних вищих навчальних закладів та установ, зокрема: Інституту педагогічних наук м. Кишинів (Молдова), Атирауського державного університету ім. Х. Досмухамедова (Казахстан), Інституту педагогіки НАПН України, Тракійського університету (м. Стара Загора, Болгарія), науковометодичного журналу “Фізика в школі" (м. Москва, Росія), Рівненського державного гуманітарного університету, Харківського Національного педагогічного університету ім.Г.С.Сковороди, Криворізького педінституту ДВНЗ "КНУ", Черкаського національного університету імені Богдана Хмельницького та ін .

3 доповідями на конференції виступили [3]:

- Девід Соколоффр, професор, президент Американської асоціації вчителів фрізики, профессор кафедри фрізики Ореґонського університету - на тему "Залучення студентів за допомогою стратегій науково обґрунтованого, активного технологізованого активного навчання" (США);

- Алекс Маццоліні, доцент кафедри фрізики і астрономії фракультету природничих наук, машинобудування і технології Свінбернського технологічного університету, екс-заступник декана з навчально-методичної роботи та експрезидент Мережі фрізичної освіти в Азії (AsPEN), Науковий керівник Групи активного навчання STEMed, учасник Дослідної групи науки, техніки і математики в освіті (STEMed), Регіональний керівник проекту Юнеско в Центральній та Східній Європі - на тему "Неефективність традиційного пасивного (трансмісивного) викладання" (Мельбурн, Австралія);

- Михайло Володимирович Тамм, кандидат фрізико-математичних наук, старший науковий співробітник, кафедра фрізики полімерів і кристалів і Лабораторія фрізичної хімії полімерів, фрізичний фракультет, Московський державний університет - на тему “Основні здобутки Ігоря Євгеновича Тамма" (Російська Федерація);

- доктор педагогічних наук, професор Садовий Микола Ілліч (ҚДПУ ім. В. Винниченка, Україна) у своїй доповіді висвітлив основні етапи життя та діяльності Ігоря Євгеновича Тамма, акцентував увагу слухачів на аспектах вшанування пам'ять Нобелівського лауреата з фрізики на Кіровоградщині та ін .

За наслідками дослідження науково-педагогічної спадщини І. Є. Тамма підготовлена і подана до участі у конкурсі - 2015/16 Стипендіальної програми “Завтра.UA” робота О. В. Єкименкової (3 курс, напрям підготовки: 6.040203 Фізика*) на тему "Патріотичне виховання молоді та широкої громадськості на основі дослідження науково-педагогічної діяльності лауреата Нобелівської премії І. Є. Тамма”. Вона стала переможницею конкурсу і виграла грант на навчання у Польщі.

В іншій темі наукових досліджень членом ЛабДФТПО М.В. Хомутенком отримано трирічний грант за програмою FIRST LEGO League та набір LEGO Mindstorms EV3. FIRST LEGO League (FLL) - освітня STEM-програма для дітей 916 років, створена некомерційною організацією FIRST та LEGO Group. У програмі грантових стипендій neuLAND (Берлін), що підтримується European Academy Berlin i Ministry of foreign affairs in Germany, отримала перемогу та фрінансування 
проект DeafCall O. В. Єкименкова.

За наслідками дослідження фрункціонування територіального освітнього округу підготовлена і подана до участі у конкурсі - 2016/17 Стипендіальної програми "Завтра.UA" робота на тему “Формування навчального середовища територіального освітнього округу методами активного навчання" (Виконавці: О. М. Трифонова, О. В. Єкименкова).

У 2018 р. проведено Міжнародну науково-практичну конференцію присвячену 60-річчю вручення І. Є. Тамму Нобелівської премії, у роботі якої взяли участь із закладів вищої освіти Арзамасу, Казахстану, Молдови, Білосусі та України.

Таким чином наукова діяльність у приведених напрямках наукової роботи $€$ реальним втіленням тамівської наукової школи у нинішню педагогічну практику, що визначають шлях для самореалізації суб'єктів навчання, фрормування наукової співпраці, підготовці наукових кадрів, метою яких $є$ :

- забезпечення всебічного наукового розвитку та мислення суб'єктів навчання, фрормуванню творчих начал підготовки до активного життя впродовж всього життя;

- інтеграція наукових знань у систему, що забезпечує розширення кругозору особистості, виробляє навички до науково-дослідницької роботи;

- формування базових компетентностей для забезпечення навчання основних дослідницьких методів дослідження природничих та суспільствознавчих наук;

- мотивація розвитку інтересу до фундаментальної наукової підготовки та науково-пошукової діяльності;

- широка комп'ютеризація освітнього процесу засобами інноваційних методів навчання, розвиток прагнення до успіху, уміння приймати власне рішення у дослідженні;

- співпраця з науковцями на принципах взаємоповаги, доброчинності, перспективності.

Висновки. Використання інноваційної методики залучення молоді до наукової діяльності (яка в цілому відображає стиль та методику роботи І. Є. Тамма) дає свої позитивні результати, що підкріплено конкретними фактами. Перспективу подальшої роботи вбачаємо у більш широкому залученні до наукової діяльності молоді: залучення учнів середньої та старшої школи до основ наукової роботи; продовження співпраці з молодими науковцями .

\section{Використана література:}

1. Воспоминания о И. Е. Тамме / отв. ред. Е. Л. Фейнберг. [3-е изд. доп.]. Москва : ИЗДАТ, 1995. 432 с. (Эпоха и личность).

2. Садовий М .І., Трифонова О. М. Місія І. С. Тамма : навч.-метод. посібн. - Кіровоград : Сабоніт, 2011. 134 c.

3. Сайт лабораторії дидактики фізики [Електронний ресурc]. URL: https://ldf-kr.at.ua/ (дата звернення 12.05.2019)

4. Фізика. Нові технологї навчання. Збірник наукових праць студентів і молодих науковців. Вип. 11. Кіровоград: Ексклюзив-Систем, 2013. - 230 с.

\section{References:}

[1] Feynberh E. L. (1995). Vospominaniya o I. Ye. Tamme : [Memoir about I. E Tamme]. Moscow, Russia : PUBLISHED 
[2] Sadovyy M. I., Tryfonova O. M. (2011). Misiya I. Ye. Tamma. [Mission I. E. Tamma]. Kirovograd, Ukraine : Saponite

[3] Sayt laboratoriyi dydaktyky fizyky [Website of the labs of the physics didactics] (2019, May 12). Education.ua. Retrieved from https://ldf-kr.at.ua/

[4] Fizyka. Novi tekhnolohiyi navchannya [Physics. New Learning Technologies.] (2013). (Out. 11). Kirovograd : Ukraine: Exclusive Systems

\section{САДОВОЙ Н. И., ПРОЦЕНКО Е. А., ДОНЕЦ Н. В. Отдельные аспекты использования научно-педагогического наследия И. Е. Тамм в современном образовательном пространстве Украины.}

Ныне в государстве сложилась не лучшая ситуация с пополнением научными кадрами новейшей генерации, поэтому проблематично стимулировать создание условий ради интереса и привлечения перспективной молодежи к научной деятельности. Методика привлечения молодежи к научной деятельности, которая использовалась И. Е. Таммом, не потеряла эффективности и в наше время, является прогрессивной, инновационной, действенной и такой, которая хорошо себя зарекомендовала годами.

В статье показано важность, актуальность научно-педагогических идей И. Е. Тамма для современного этапа развития педагогики и истории педагогики. Раскрыто систему привлечения молодежи к научной деятельности на основе исследования научно-педагогического наследия И. Е. Тамма в учреждениях высшего образования Украины. Среди таких заведений высшего образования можно выделить научные иколь Центрально педагогического университета им.В. Винниченко. Работа, проводимая в данном направлении является результативной и требующей освещения. В статье показаны результаты семилетней деятельности Лаборатории дидактики физики, технологии и профессионального образования (ЛАБДФТПО) Института педагогики АПН Украинь в Центральногосударственном педагогическом университете имени Владимира Винниченко, раскрытии подходы к организачии деятельности молодых ученьх. Использование инновационной методики привлечения молодежи к научной деятельности (которая в целом отражает стиль и методику работь И.Е.Тамма) дает свои положительные результаты, подробнее рассмотрены в статье.

Ключевые слова: И. Е. Тамм, образование, педагогическое наследие.

SADOVYi M., Protsenko E., Donets N. Specific aspects of use of scientific and pedagogical heritage I. E. Tamma in the modern educational space of Ukraine.

At present, the situation in the country is not the best situation with the replenishment of scientific personnel of the new generation, so it is problematic to stimulate the creation of conditions for the interest and involvement of promising young people in scientific activity. The technique of involving young people in scientific activity, used by IE Tamm, has not lost its effectiveness and is nowadays progressive, innovative, effective and well-proven over the years.

The article shows the importance, relevance of scientific and pedagogical ideas of I. E. Tamma for the modern stage of development of pedagogy and history of pedagogy. The system of attraction of young people to scientific activity on the basis of research of scientific and pedagogical heritage of I. E. Tamma in higher education institutions of Ukraine. Among such institutions of higher education can be distinguished scientific schools of the Central Ukrainian Pedagogical University. V. Vynnychenko The work carried out in this direction is productive and needs to be highlighted. The article presents the results of the seven-year activity of the Laboratory of Didactics of Physics, Technologies and Professional Education (LABDFTPO) of the Institute of Pedagogy of the National Academy of Pedagogical Sciences of Ukraine at the Volodymyr Vynnychenko Central Ukrainian State Pedagogical University, disclosing approaches to the organization of the activities of young scientists. The use of an innovative technique for attracting young people to scientific activity (which generally reflects the style and methodology of I. E Tamm) gives his positive results, which is discussed in more detail in the article.

Keywords: I. E. Tamm, education, pedagogical heritage. 